\title{
Nucleic acid content in tissue of the fish N. notopterus collected from different aquatic bodies
}

\author{
K. Ravikiran*, R. S. Kulkarni \\ Fish Endocrinology Research Laboratory, \\ Department of Post Graduate Studies and Research in Zoology, Gulbarga University, \\ Gulbarga - 585 106, Karnataka, India \\ *E-mail address: ravikirankattimani@gmail.com
}

\begin{abstract}
Nucleic acid content in brain, liver, kidney and gonads of the freshwater fish Notopterus notopterus collected from different aquatic bodies were studied during pre-spawning phase of the reproductive cycle. The three different aquatic bodies selected were Saradgi nala, Bennithora River and Bheema River and their physiochemical parameters also studied. The present study of nucleic acid content in brain, liver, kidney and gonads of the fish Notopterus notopterus collected from aquatic body Bennithora River shows normal levels of the nucleic acid as compared to that of fish from other two aquatic bodies. The normal content of nucleic acid content of $N$. notoptuers in the aquatic body Bennithora may be due to favorable environmental condition for survival, growth, distribution and reproductive activity.
\end{abstract}

Keywords: different aquatic bodies; DNA; RNA; Notopteru

\section{INTRODUCTION}

The availability of a particular species in wild in large numbers reflects that the fish is thriving well in the environment, which is most suitable for its survival, growth and breading activities. In this context it becomes necessary to identify the suitability of the environment for that particular species inhibiting the area under natural conditions. The ultimate factors such as water quality oxygen availability temperature, predation, food availability and the proximate factors including predictive cues are important for fish reproduction. Since, $N$. notopterus is available in large number in the aquatic bodies around Gulbarga, there is every possibility that the factors available of fish are favorable and in order to understand the existing environmental condition favoring the success of breeding and their survival.

The physiology of living organism is the manifestation of intricate and complex biochemical processes. Fishes encounter fluctuations in the external macro environmental cues e.g., photoperiod, temperature, water quality etc., which are perceived by fish through hormonal/neurohormonal /hormonal messages. These messages at various target tissues are translated into different biochemical reactions regulating physiology of the tissue. Because of variation in ambient temperature and photoperiod, the internal milieu of fish changes constantly and thus all the above interacting factors collectively determine the nature and extent of the response of fish. 
Growth rate in fish can be assessed by means of the RNA/DNA ratio, a sensitive biochemical measure of short-term growth (Bulow, 1987). Use of the ratio as a growth index is based on the premise that the cell content of RNA is related to the amount of protein synthesis and thus reflects recent growth and nutritional condition (Buckley and Lough, 1987).

DNA cell content remains fairly constant and serves to normalize the measured RNA. Growth rate is correlated with the RNA/DNA ratio, and changes in this ratio reflect recent changes in growth rate (Bulow, 1987). Although RNA/DNA ratios have often been examined in marine fish, few studies have measured RNA/DNA ratios in freshwater fish under natural conditions (Audet and Couture, 2003; Tardif et al., 2005).

Approximately 4 days are required for the RNA/DNA ratio to change significantly in response to changes in food availability for juvenile Atlantic salmon (Salmo salar) in the laboratory (Arndt et al., 1996), whereas responses to temperature fluctuations can span over a period of up to 1 week for larval yellow perch in the field (Tardif et al., 2005). RNA/DNA ratios measured in field-caught fish may be particularly useful for linking environmental effects to physiological processes because they provide accurate estimates of growth responses to short-term environmental fluctuations.

The use of RNA/DNA ratios, which respond rapidly to changes in food and temperature conditions, provides a more precise evaluation of short-term environmental influences than would be possible by means of more conventional methods for studying growth, such as analyses of annual increments on hard structures. Uncovering the impact of seasonal fluctuations in temperature and water level on fish growth should allow for better understanding of how biotic processes, such as growth rates, are regulated in shallow fluvial lakes.

At a larger scale, knowledge about the effects of short-term environmental fluctuations on fish growth can yield insight into the potential impact of long-term climatic changes on fish production.

The present study is aimed to find out, is there any difference in nucleic acid contents in certain organs such as brain, liver, kidney and gonads of the fish collected from different aquatic bodies (having different habitat).

\section{MATERIALS AND METHODS}

Freshwater fish $N$. notopterus is selected for the present study. This fish is locally available in ponds, tanks and rivers in and around Gulbarga city. Three aquatic bodies were selected for collection of the fish $N$. notopterus, the aquatic body-1 situated at Saradgi which is a small water stream (Nala) $15 \mathrm{kms}$ away from Gulbarga.

The aquatic body-2 Bennithora River situated at Korikotta village $20 \mathrm{kms}$ from Gulbarga city. The aquatic body-3 is Bheema River situated at Katti Sangavi is $30 \mathrm{kms}$ away from Gulbarga. 


\section{STUDY OF SOME PHYSICOCHEMICAL PARAMETERS OF WATER BODIES}

I. Dissolved oxygen (DO): The water sample was collected from different spots of the three aquatic bodies in to $250 \mathrm{ml}$ reagent bottles avoiding any kind of aggregation before commencing estimations. The different samples from three aquatic bodies were labeled for identification. The labeled samples were fixed immediately at the collection spot using alkaline iodide and manganese sulphate and brought to the laboratory. The dissolved oxygen was determined by using modified Winkler's method APHA, AWWA and WCPF (1985).

II. Hydrogen ion concentration (pH): The $\mathrm{pH}$ was determined by small hard $\mathrm{pH}$ meter dipping in to the water at the site of collection spots directly using LT-70-PH and held digital $\mathrm{pH}$ meter.

III. Temperature: Water temperature was recorded at the site of collection spots using an ordinary mercury thermometer to the nearest of $0.1{ }^{\circ} \mathrm{C}$ (water temperature at depth of $8 \mathrm{~cm})$.

IV. The nucleic acid content such as DNA and RNA were determined in brain, liver, kidney and gonads of the freshwater fish $N$. notopterus collected from three different aquatic bodies. Nucleic acid content were determined by using the following methods. Estimation of DNA by Diphenylamine method of Schneider (1940)

Estimation of RNA by Orcinol method Schneider (1940)

In all the cases six observation were made and the results were expressed as arithmetic mean with their standard deviation, standard error and student " $t$ " test were made as described by Suedecur (1946) and Fisher (1963).

\section{RESULTS AND DISCUSSION}

The fish $N$. notopterus is available in large numbers in the aquatic bodies in and around Gulbarga (Fig. 1) and are quite common in the aquatic bodies throughout the year.

They can be collected using cast net with the help of fishermen. The presence of this fish in the aquatic body can be identified through its surfacing action. This fish comes to the surface for gulping air; the air is stored inside the air bladder situated in the dorsal region inside the body. The feeding of this comprises of some aquatic insects, weeds, small fishes, feeding activity increases after spawning in this fish. The fish builds nets and spawns among the aquatic weeds including submerged branches of acacia plant.

\section{1. Physicochemical parameters observation}

I. Dissolved oxygen (DO): In all the three aquatic bodies studied the dissolved oxygen (DO) level is high in aquatic body 2 followed by aquatic body 1 and 3 (Table 1, Fig. 2). The dissolved oxygen values of aquatic bodies 1, 2 and 3 are 10.8, 12.6 and 9.5 $\mathrm{mg} / \mathrm{l}$ respectively.

II. Hydrogen ion concentration (pH): The $\mathrm{pH}$ value of aquatic body 1, 2, 3 studied are in the following order $8.4,8.5$ and 8.9 respectively.

III. Temperature: In all the three aquatic bodies studied the water temperature of the aquatic body- 2 seems to be higher. The readings of the thermometer for the three different aquatic bodies are $29^{\circ} \mathrm{C}, 32^{\circ} \mathrm{C}$, and $30^{\circ} \mathrm{C}$ respectively. 


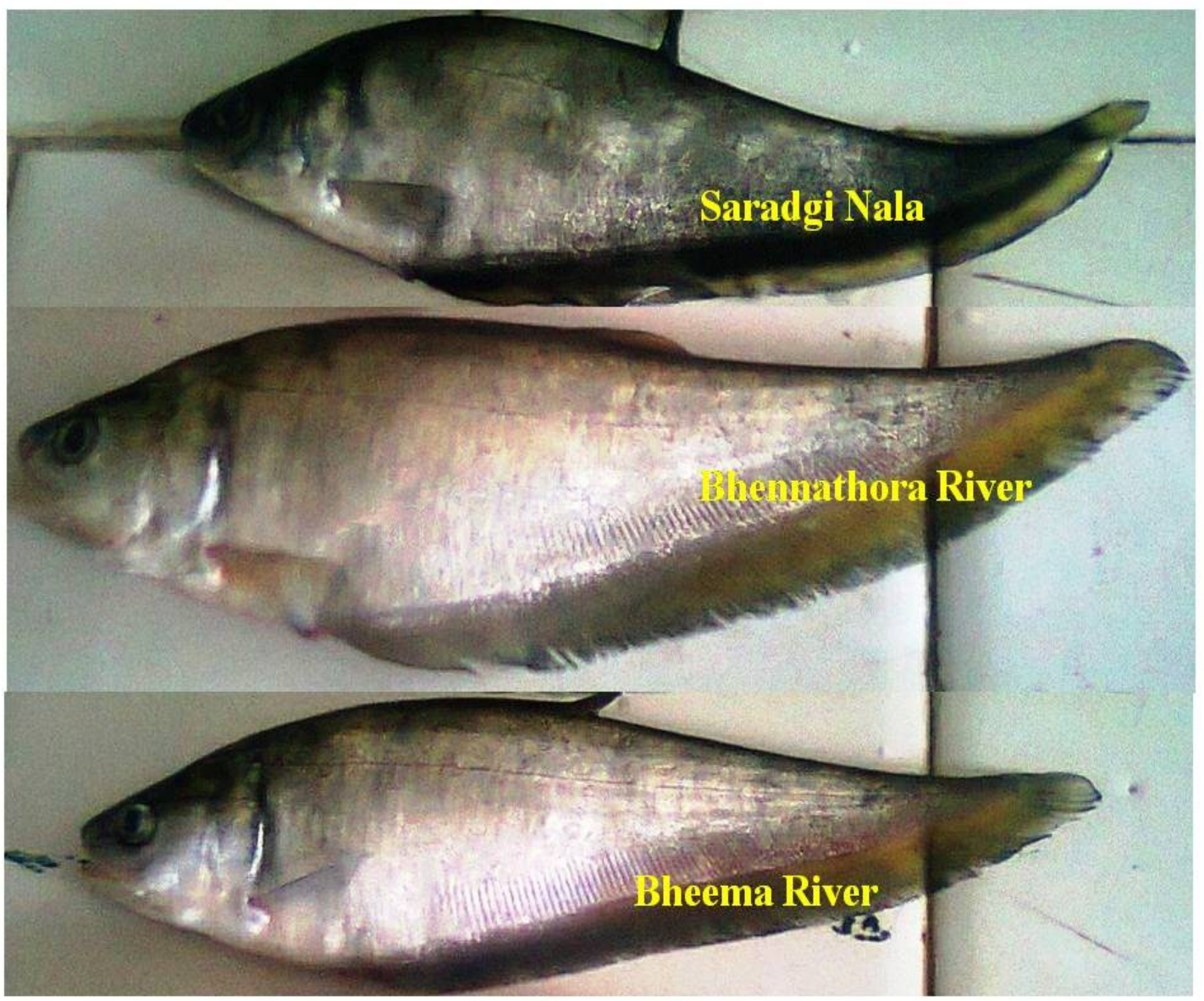

Fig. 1. Showing freshwater fish N. notopterus collected from three different aquatic bodies during prespawning phase.

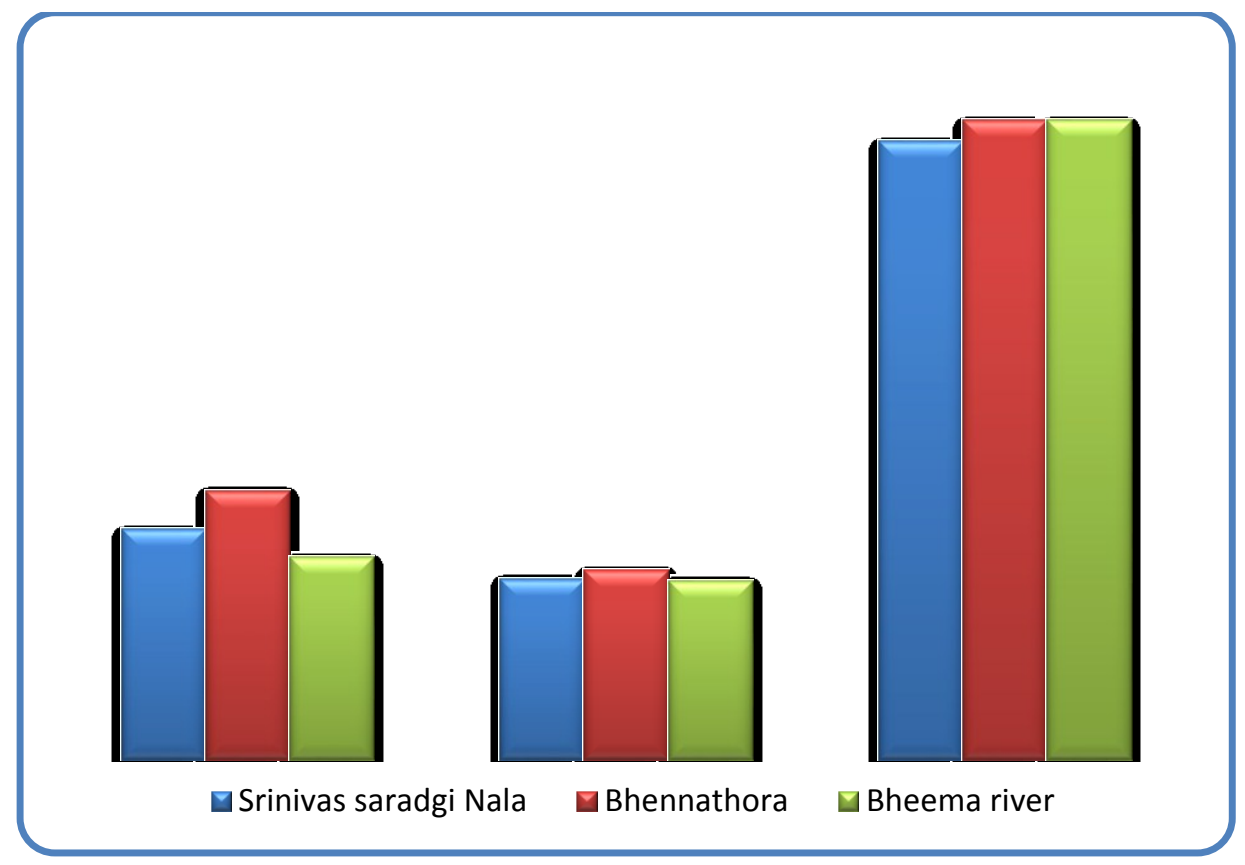

Fig. 2. Showing physicochemical parameters of the fish, $N$. notopterus collected from different aquatic bodies of Gulbarga. 
Table 1. Showing some physicochemical parameters of three different aquatic bodies of Gulbarga district.

\begin{tabular}{|l|c|c|c|}
\hline \multicolumn{1}{|c|}{ Aquatic body } & $\begin{array}{c}\text { Dissolved oxygen } \\
\text { (DO) (mg/l) }\end{array}$ & $\mathbf{p H}$ & Temperature \\
\hline 1. Saradgi Nala & $10.8 \mathrm{mg} / 1$ & 8.5 & $29^{\circ} \mathrm{C}$ \\
\hline 2. Bennithora river & $12.6 \mathrm{mg} / 1$ & 8.9 & $30^{\circ} \mathrm{C}$ \\
\hline 3. Bheema river & $9.5 \mathrm{mg} / 1$ & 8.4 & $30^{\circ} \mathrm{C}$ \\
\hline
\end{tabular}

The above results on various aspects including morphometric studies (length and weight of the fish tissues). Condition of the fish, nucleic acid content in the tissues such as brain, liver, kidney and gonads in the fish collected from three aquatic bodies during particular season prespawning phase in which phase the fish undergoes active gonadal growth.

\section{2. Nucleic acid content}

The nucleic acid content in brain, liver, kidney and gonads was studied in the fish $N$. notopterus from three different aquatic bodies during pre-spawning phase of the reproductive cycle (Table 2, Fig. 3).

Table 2. Showing nucleic acid content in brain, liver, kidney and gonads in the freshwater fish $N$. notopterus collected from three different aquatic bodies during prespawning phase $(\mathrm{mg} / \mathrm{ml})$.

\begin{tabular}{|l|c|c|c|c|}
\hline \multicolumn{1}{|c|}{$\begin{array}{c}\text { DIFFERENT } \\
\text { AQUATIC BODIES/ } \\
\text { ORGANS }\end{array}$} & \multicolumn{2}{c|}{ BRAIN } & \multicolumn{2}{c|}{ LIVER } \\
\cline { 2 - 5 } & DNA & RNA & DNA & RNA \\
\hline \multirow{2}{*}{ 1. Saradgi Nala } & $102 \pm 1.78$ & $39 \pm 1.3$ & $100 \pm 2.10$ & $43.2 \pm 1.3$ \\
& $\mathrm{SE} \pm 0.72$ & $\mathrm{SE} \pm 0.54$ & $\mathrm{SE} \pm 0.97$ & $\mathrm{SE} \pm 0.54$ \\
\hline \multirow{2}{*}{ 2. Bennithora river } & $104.6 \pm 1$ & $40 \pm 0.61$ & $110 \pm 2.12$ & $44.6 \pm 0.73$ \\
& $\mathrm{SE} \pm 0.41$ & $\mathrm{SE} \pm 0.25$ & $\mathrm{SE} \pm 0.86$ & $\mathrm{SE} \pm 0.30$ \\
\hline \multirow{2}{*}{ 3. Bheema river } & $105 \pm 1$ & $42 \pm 1$ & $111 \pm 2.12$ & $45 \pm 0.73$ \\
& $\mathrm{SE} \pm 0.61$ & $\mathrm{SE} \pm 0.65$ & $\mathrm{SE} \pm 0.56$ & $\mathrm{SE} \pm 0.45$ \\
\hline
\end{tabular}

\begin{tabular}{|c|c|c|c|c|}
\hline \multirow{2}{*}{$\begin{array}{c}\text { DIFFERENT } \\
\text { AQUATIC BODIES/ } \\
\text { ORGANS }\end{array}$} & \multicolumn{2}{|c|}{ KIDNEY } & \multicolumn{2}{|c|}{ GONADS } \\
\hline & DNA & RNA & DNA & RNA \\
\hline 1. Saradgi Nala & $\begin{array}{l}51 \pm 1.40 \\
\mathrm{SE} \pm 0.57\end{array}$ & $\begin{array}{l}40.2+1.7 \\
\mathrm{SE} \pm 0.70\end{array}$ & $\begin{array}{l}108 \pm 1.74 \\
\mathrm{SE} \pm 0.71\end{array}$ & $\begin{array}{l}44.8 \pm 1.6 \\
\mathrm{SE} \pm 0.66\end{array}$ \\
\hline 2. Bennithora river & $\begin{array}{l}51.5 \pm 1.7 \\
\mathrm{SE} \pm 0.70\end{array}$ & $\begin{array}{l}42.7 \pm 1.2 \\
\mathrm{SE} \pm 0.49\end{array}$ & $\begin{array}{c}112.5 \\
+2.12 \\
\mathrm{SE}+0.86 \\
\end{array}$ & $\begin{array}{l}45.5 \pm 2.3 \\
\mathrm{SE} \pm 0.94\end{array}$ \\
\hline 3. Bheema river & $\begin{array}{c}52 \pm 1.7 \\
S E \pm 0.40\end{array}$ & $\begin{array}{c}43 \pm 1.2 \\
\mathrm{SE} \pm 0.60\end{array}$ & $\begin{array}{c}113 \pm 2 \\
S E \pm 0.56\end{array}$ & $\begin{array}{c}46 \pm 1.9 \\
\mathrm{SE} \pm 0.54\end{array}$ \\
\hline
\end{tabular}

* Each value is expressed as Mean, Standard Deviation and Standard Error of six observations. 

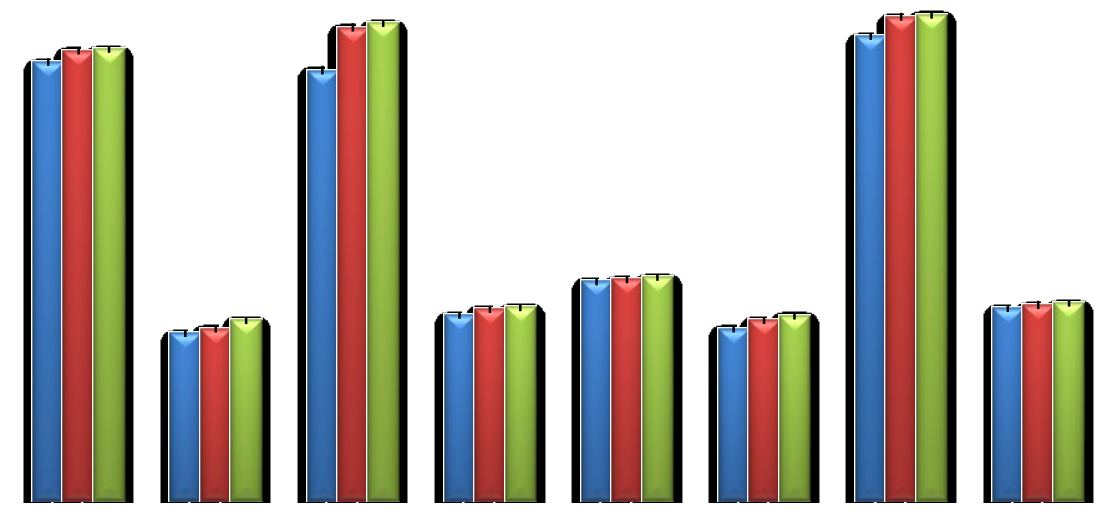

$\square$ Srinivas saradgi Nala

Bhennathora

$\square$ Bheema river

Fig. 3. Showing nucleic acid content of $N$. notopterus collected from different aquatic bodies of Gulbarga.

\section{2. 1. Saradgi Nala}

DNA: In $N$. notopterus fish gonads contain higher amount of DNA then other tissues; brain has $102 \pm 1.78$, liver $100 \pm 2.10$, kidney $51 \pm 1.40$, gonads $108 \pm 1.74$.

The degree of DNA content in gonads $>$ brain $>$ liver $>$ kidney.

RNA: The RNA content also exhibited similar to that of DNA having higher in the gonads. Brain has $39 \pm 1.3$, liver $43.2 \pm 1.3$, kidney $40.2 \pm 1.7$, gonads $44.8 \pm 1.6$.

The degree of RNA content in gonads $>$ liver $>$ kidney $>$ brain.

The ratio of DNA/RNA between the tissues of fish indicates the brain has 2:1, liver $2: 1$, gonads $2: 1$ and only in kidney it is $1: 1$

\section{2. 2. Bennithora river}

DNA: In $N$. notopterus fish gonads contain higher amount of DNA then other tissues; brain has $104.6 \pm 1$, liver $110 \pm 2.12$, kidney $42.7 \pm 1.2$, gonads $112.5 \pm 2.12$.

The degree of DNA content in gonads $>$ liver $>$ brain $>$ kidney.

RNA: The RNA content also exhibited similar to that of DNA having higher in the gonads. Brain has $40 \pm 0.61$, liver $44.6 \pm 0.73$, kidney $42.7 \pm 1.2$, gonads $45.5 \pm 2.3$.

The degree of RNA content in gonads $>$ liver $>$ kidney $>$ brain.

The ratio of DNA/RNA between the tissues of fish indicates the brain has $2: 1$, liver $2: 1$, gonads $2: 1$ and only in kidney it is $1: 1$.

\section{2. 3. Bheema river}

DNA: In N. notopterus fish gonads contain higher amount of DNA then other tissues; brain has $105 \pm 1$, liver $111 \pm 2.12$, kidney $52 \pm 1.7$, gonads $113 \pm 2$.

The degree of DNA content in gonads $>$ liver $>$ brain $>$ kidney. 
RNA: The RNA content also exhibited similar to that of DNA having higher in the gonads. Brain has $42 \pm 1$, liver $45 \pm 0.73$, kidney $43 \pm 1.2$, gonads $46 \pm 1.9$.

The degree of RNA content in gonads $>$ liver $>$ kidney $>$ brain.

The ratio of DNA/RNA between the tissues of fish indicates the brain has 2:1, liver $2: 1$, gonads $2: 1$ and only in kidney it is $1: 1$.

Kiran and Waghary (1998) have studied the food and feeding habits of this fish in Saroornagar Lake (Hyderabad) and found that the fish N. notopteus is corni-omnivorous, euryphagic and bottom feeder. Feeding intensity is maximum in summer and minimum in the winter which is related to maturity. The fish is capable of adjusting and widening which is related to maturity. The fish is capable of adjusting and widening its food spectrum, when preferred items become scare. They appear to thrive on other food easily and readily available in the area.

The dissolved oxygen content of the three water bodies has been studied. The aquatic body-2 is having more amount of dissolved oxygen in comparison to that of other two water bodies. Dissolved oxygen in the water bodies 1, 2, 3 are 10.8, 12.6 and $9.5 \mathrm{mg} / 1$ respectively. In all the three aquatic bodies in the present study deficiency of dissolved oxygen was not recorded. There is field and experimental evidence that low oxygen was not recorded. There is field and experimental evidence that low oxygen levels are inimical to the eggs and fry of various freshwater species, especially before the development of the opercula and thus a fractional buccal pump (Spoor, 1997). The fish N. notopterus spawns eggs which are quite big and found to be attached to the small branches and leaves of Acacia plants submerged at the water surface and seem to guard the eggs. Lam (1983) has also suggests high level of oxygen triggers and enhance spawning in the carp C. carpio.

The hydrogen ion concentration $(\mathrm{pH})$ of the three aquatic bodies indicates that the $\mathrm{pH}$ is found to be more in the aquatic body-2. The alkaline nature of water indicates suitability of water for aquatic organism (Pandey and Lal, 1995). Hence, the field observations on large species of fish hint at the importance of adequate food reserves for gonadal recrudescence and breeding.

In this study water temperature of three water bodies from which the fish $N$. notopterus has been collected was studied. The temperature is considered as one of the important factors of ecological investigation (Manna et al., 1997).

According of Jhingran (1982) a prior knowledge of maximum and minimum water temperature of the water body is essential for selecting suitable species for culture operation. Fish being Poikilothermic, it is obvious that temperature must play important role.

Bye (1990) while reviewing reproductive seasonality in teleosts with reference to environmental influence on temperate marine fishes described that the temperature influences the rate of all metabolic processes and so far poikilothermic animals such as fish there is invariably a relationship between the environmental temperature and the metabolic depending processes related to reproduction, growth, feeding rates and food conversion efficacy as well as the availability of food are all affected by temperature and these have important implications on game gametogenesis and spawning.

The temperature regime in the present study seems to be favoaurble for the fish $N$. notopterus for its breeding and metabolic activity in all the aquatic bodies.

Nucleic acid plays a central role in cell function and cell structure. Nucleic acid are higher molecular weight polypeptides. They are not only responsible for comprising the structure of cell but are involved in all the aspects of cell physiology such as catalysis, tissue repair, building and defense reactions etc. through hormones, they regulates the metabolic aspects of the animal. The protein synthesis is affected by xenobiotics, environmental fluctuations and stress. 
In the present study the tissues DNA/RNA of the fish, $N$. notopterus collected from water body-2 shows normal and optimum level needed for metabolic activity and growth compared to that of fish from other water bodies. Environmental agents play a vital role in altering the metabolism of an organism (Knox and Greengard, 1965).

Seasonal variations of larval growth and RNA/DNA ratios were analyzed in relation to environmental variables. Oceanographic features in the area of study are strongly influenced by the flow of nutrient-poor Atlantic water, which enters the Alboran Sea through the Gibraltar Strait. In 1997, the influence of Atlantic water was stronger in spring than in winter, leading to lower salinity in spring 1997. The predominance of Atlantic waters could lower chlorophyll-a concentration in spring 1997 than expected for this season. In addition, lower micro zooplankton biomass was observed in spring 1997 than in winter 1997. In concordance with micro zooplankton biomass, the RNA/DNA ratio of sardine larvae was higher in winter 1997 than in spring 1998. No seasonal differences in somatic or otolith growth rates were observed in 1997, which could be due to a time lag in the response of larval growth to changing environmental conditions. Unlike the previous year, during 1998, no seasonal changes were observed in the amount of incoming Atlantic water, as evidenced by sanity values. In 1998, temperature and micro zooplankton biomass were higher in spring than in winter, causing higher somatic and otolith growth rates in spring 1998 compared to winter 1998 could be responsible of a decline in the RNA/DNA ratio of spring spawned sardine larvae in comparison to winter spawned larvae. Larval growth and RNA/DNA ratios may show a different response to changes in the environment, particularly temperature knows that temperature. It is known that temperature has a positive effect on growth rates but it has a negative effect on the RNA/DNA ratios, then it is recommended to bear in mind these effects, particularly when joint analysis of larval growth and RNA/DNA ratios are carried out (Teodoro Ramirez et al., 2004).

In the present study the brain, liver, kidney and gonads of the fish $N$. notopterus collected form aquatic body Bennithora River shows normal level of nucleic acids as compared to that of fish from other two aquatic bodies. The normal content of nucleic acid in of brain, liver, kidney and gonads of freshwater fish $N$. notopterus in the aquatic body 2 may be due to favourable environmental condition for survival, growth and distribution reproductive activity.

\section{CONCLUSIONS}

In conclusion, based on the results obtained for nucleic acid contents show that the fish $N$. notopterus collected from different aquatic bodies are healthy and have favorable environmental conditions to thrive well. However, there is difference between the aquatic bodies. The aquatic body Bennithora River provides better environmental conditions compared to others and provides favorable condition to the fish followed by Bheema River and Saradgi Nala. 
Further, it is suggested from the above studies that aquatic body water body-2, provides proper environmental conditions which is quite favourable for the fish, $N$. notopterus to thrive well as the fish collected from this water body has increased levels of tissues nucleic acid content. The aquatic body-2 has high dissolved oxygen, proper $\mathrm{pH}$, temperature and has high submerged vegetation which helps the fish for proper food availability and a favourable breeding ground and growth.

\section{References}

[1] APHA, AWWA, WCPE (1985). Standard methods for the examination of waters and waste water, $16^{\text {th }}$ Ed. Washington, D. C.

[2] Arndt S.K.A., Benfey T.J., Cunjak R.A., Journal of Fish Biology 49 (1996) 257-276.

[3] Audet D., Couture P., Can. J. Fish Aquat. Sci., 60 (2003) 269-278.

[4] Buckley L.J., Laugh R.G., Can. J. Fish. Aquat. Sci. 44 (1987) 11-25.

[5] Bulow F.J. (1987). RNA-DNA ratios as indicators of growth in a fish: A review pp. 45-64. In the age and growth of fish R.C. Summerfelt and G.E. Hall Edit., The Lowa State University Press, Ames, Lowa, U.S.A.

[6] Bye V.J. (1990). In "Reproductive seasonality in teleosts": "Environmental influences". Ed. Scott, A.P. and T.J. Lam, (CRC Press, Inc. Boca Raton, Florida).

[7] Fisher R. (1963). Statistical Methods for Research Worker Ed 6, Edinburgh.

[8] Jhingarn V.G. (1982). Fish and fisheries of India. In Hindustan Publishing Corporation, New Delhi, P. 666.

[9] Kiran U.G., Waghary S., Indian J. Fish 45(3) (1998) 355-359.

[10] Knox W.E. and Greengard O. (1965). The regulation of some enzymes of nitrogen metabolism: An introduction to enzyme physiology. In G. Weber (Ed). Adv. in Enzyme Regulation, Vol. 3. Pergamon Press, Oxford, p. 247.

[11] Lam J.J. (1983). Environmental influences and gonadal activity in fish; In "Fish physiology" (Hoar, W.S., Randal, D.J. and Donaldson, E.M. Eds) Vol. 1X, Reproduction Part-B, Academic Press, New York, pp. 66-166.

[12] Pandey Kausual Kumar and Lal, M.S. (1995). Limnological studies of Garhwal Himalayan Hill Steam Kanda Gad: Seasonal Fluctuation in Abiotic Profile, U.P. 174-246. India J. Freshwater Biol., 7(1):7-11.Manna et al., 1997

[13] Schneider W.C. (1940). Academic Press, New York, pp. 235-340.

[14] Schneider W.C. (1957). Determination of nucleic acid in tissues by pentose analysis In: Methods in Enzymology, Vol. 3 (S.P. Colowick and N.O. Kaplan, ed). Academic Press, New York, pp. 680-684.

[15] Spoor W.A. (1997). Oxygen requirement of embryos and larvae of the large mouth bass, Micropterus salmoides (Lacepede). J. Fish Biol., 11:77. In: Reproductive Seasonality in Teleosts: Envi. Influences General Introduction, A.D. Mullio (Eds. A.D. Mullio, A.P. Scott, T.J. Lam) CRC Press. 
[16] Suedecur C.W. (1946). Statistical methods low a state college press, Amesiowa.

[17] Tardif D., Glémet H., Brodeur P., Mingelbier M., Canadian Journal of Fisheries and Aquatic Sciences 62 (2005) 2211-2218.

[18] Teodoro Ramirez, Dolores Cortes, Alberto Garcia and Angel Carpena (2004). Seasonal Variations of RNA/DNA ratio's and growth rates of Alboran sea Sardine larvae (Sardine pilchardus) Instituto Espanol de Oceanografia, Centro Oceanografico de Malaga, Puerto pesquero s/n, Apdo. 285-296. Fuengirola, Malaga, Spain. 